\title{
EFEKTIFITAS LKPD DENGAN PENDEKATAN SAINTIFIK UNTUK MENINGKATKAN PEMAHAMAN KONSEP MATEMATIKA SISWA KELAS VIII SMP NEGERI 3 KOTA BENGKULU
}

\author{
Agung Setiabudi $^{1}$, Agus Susanta $^{2}$, Della Maulidiya ${ }^{3}$ \\ Program Studi Pendidikan Matematika FKIP Universitas Bengkulu \\ email: 1 aghung.22@gmail.com, ${ }^{2}$ agusunib@yahoo.com, ${ }^{3}$ della.maulidiya@unib.ac.id
}

\begin{abstract}
Abstrak
Penelitian ini bertujuan menghasilkan Lembar Kerja Peserta Didik dengan Pendekatan Saintifik pada Materi Bangun Ruang Sisi Datar untuk Meningkatkan Pemahaman Konep Matematika Siswa Kelas VIII di SMPN 3 Kota Bengkulu yang memenuhi kategori efektif. Penelitian ini adalah penelitian pengembangan (Research and Development) dengan memodifikasi model 4D Thiagarajan menjadi 3 tahapan yaitu tahap pendefinisian (define), tahap perancangan (design), dan tahap pengembangan (develop) yang terdiri dari validitas, kepraktisan, dan efektifitas. Efektifitas LKPD diuji pada tiga puluh dua peserta didik di kelas VIII 1 SMP Negeri 3 Kota Bengkulu semester genap tahun ajaran 2017/2018. Instrumen penelitian terdiri dari lembar efektifitas. Hasil penelitian menunjukkan bahwa Lembar Kerja Peserta Didik Dengan Pendekatan Saintifik Pada Materi Bangun Ruang Sisi Datar Untuk Meningkatkan Pemahaman Konsep Matematika Siswa Kelas VIII Di SMPN 3 Kota Bengkulu termasuk dalam kategori efektif berdasarkan : 1) respon peserta didik dengan skor rata-rata 63,88 dalam kategori sangat baik; 2) aktivitas peserta didik dengan skor rata-rata 66,5 dalam kategori sangat baik dan; 3) hasil belajar peserta didik mencapai ketuntasan klasikal 81,25\%.
\end{abstract}

Kata Kunci : Efektifitas, Lembar Kerja Peserta Didik, Pendekatan Saintifik, Pemahaman Konsep matematika

\begin{abstract}
This research aims to develop the learners' worksheet with the Scientific Approach in Polyhedron Material Facility to Increase the Understanding of Mathematical Concept of the 8th-grade students at the SMPN 3 Kota Bengkulu that meets effective category. Type of research used development research (Reasearch and Development) by modifying the 4D Thiagarajan model into 3 phase, which are define phase, design phase, and development phase consisting of validity, practicality, and effectiveness. Validation has been done by 3 validators. The effectiveness of LKPD was tested on thirty-two students in the 8th-grade 1 SMP Negeri 3 Kota Bengkulu in the even semester of the 2017/2018 academic year. The research instruments consist of effectiveness. The results showed that the Students' worksheet with Scientific Approach in Polyhedron Material to improve the Understanding of Student in Mathematical Concept of the 8th grade in SMPN 3 Kota Bengkulu includes in the category as follows effective on the basis of: 1) the response of learners with an average score of 63.88 in very good category; 2) the activity of learners with an average score of 66.5 in a very good category and; 3) learning outcomes of learners achieve classical completeness $81,25 \%$.
\end{abstract}

Keywords : Effectiveness, Students' Worksheet, Scientific Approach, Understanding Mathematical

\section{PENDAHULUAN}

Matematika merupakan salah satu disiplin ilmu yang memiliki kekhasan dibandingkan dengan ilmu yang lain. Sehingga matematika menjadi salah satu solusi untuk menyelesaikan masalah dalam kehidupan sosial manusia. Masykur dan Abdul (2008) berpendapat bahwa proses pembelajaran matematika yang lebih baik dan berkualitas di sekolah merupakan suatu keharusan yang tidak dapat ditawar lagi. 
Pembelajaran matematika bukan hanya menekankan pada kemampuan berhitung saja, tapi juga harus bisa menguasi konsep-konsep matematika yang abstrak (Ibrahim dan Suparni, 2008:121). Hal ini sejalan dengan pendapat Dahar (Murizal, 2012) menyebutkan “jika ibaratkan konsep-konsep merupakan batu-batu pembangunan dalam berfikir", maka akan sulit bagi siswa untuk mencapai proses pembelajaran yang lebih tinggi jika belum bisa memahami konsep. Oleh karena itu materi atau pemahaman konsep matematika harus dikuasi dengan baik oleh siswa untuk diterapkan dalam proses pembelajaran.

Ibrahim (2015: 371) menyatakan bahwa kurikulum 2013 diterapkan bertujuan untuk membentuk proses pembelajaran yang berpusat pada peserta didik dan pendidik berperan sebagai fasilitator, hal tersebut dilakukan untuk mengubah paradigma lama menuju kemajuan dalam sistem pendidikan.

Prastowo (2011 : 204) secara lebih rinci mengemukakan bahwa LKPD merupakan bahan ajar cetak berupa lembaran kertas berisi materi, ringkasan, dan petunjuk-petunjuk pelaksanaan tugas pembelajaran yang harus dikerjakan oleh peserta didik yang mengacu pada kompetensi dasar yang harus dicapai.

Prastowo (2011 : 206) menyebutkan ada beberapa tujuan pembuatan LKPD yakni: 1) menyajikan bahan ajar yang memudahkan peserta didik untuk berinteraksi dengan materi yang diberikan; 2) menyajikan tugas-tugas yang meningkatkan penguasaan peserta didik terhadap materi yang diberikan; 3) melatih kemandirian belajar peserta didik; 4) memudahkan pendidik dalam memberikan tugas kepada peserta didik. Untuk mengembangkan bahan ajar yang berupa LKPD maka tujuan dari LKPD ini haru diketahui.

Hosnan (2014:35) menjelaskan bahwa pendekatan saintifik sangat relevan dengan tiga teori belajar terkemuka yaitu teori Bruner, teori Piaget, dan teori Vygotsky. Teori belajar Bruner yang disebut juga teori belajar penemuan mengemukakan bahwa dengan proses penemuan, siswa akan mendapatkan sensasi/kepuasan intelektual dan akan memperkuat ingatan. Teori belajar Piaget mengatakan bahwa belajar berkaitan dengan pembentukan dan perkembangan skema sebagai akibat dari terjadinya adaptasi. Teori belajar Vygotsky menyatakan bahwa pembelajaran terjadi apabila peserta didik bekerja atau belajar menangani tugas-tugas yang belum dipelajari namun tugas-tugas itu masih berada dalam jangkauan kemampuan peserta didik. Hal ini menjadi alasan mengapa pendekatan saintifik harus diterapkan pada setiap jenjang pendidikan di indonesia.

Afrilianto (Purwaningsih dan Ariyanto, 2016 : 1) menyatakan bahwa "Pemahaman konsep matematika adalah kemampuan dalam memahami konsep, operasi, dan relasi matematika". Peserta didik mampu memahami konsep matematika misalnya peserta didik mampu menangkap makna dalam mempelajari luas permukaan limas yang merupakan luas dari seluruh sisi limas atau luas dari sisi alas yang berbentuk persegi dan sisi tegak yang berbentuk segitiga. Peserta didik mampu memahami operasi matematika misalnya peserta didik mampu melakukan perhitungan jumlah, kurang, bagi, dan kali pada operasi hitung bentuk aljabar. Peserta didik memahami relasi matematika misalnya peserta didik mampu menghubungkan rumus luas permukaan limas dengan rumus luas permukaan kubus. Jadi dengan pemahaman konsep peserta didik akan lebih mudah mengingat rumus dan menyelesaikan soal yang diberikan yaitu pada materi bangun datar sisi datar. Pemahaman konsep juga mempengaruhi proses transfer belajar dan mempengaruhi kepercayaan karena adanya persamaan kontek lama dan konteks baru.

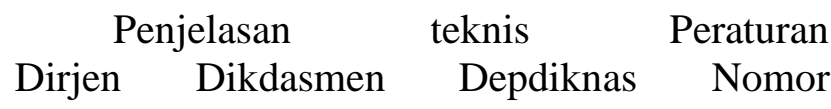
506/C/Kep/PP/2004 tanggal 11 November 2004 tentang rapor pernah diuraikan bahwa indikator siswa memahami konsep matematika adalah sebagai berikut

1. Menyatakan ulang sebuah konsep.

2. Mengklasifikasi objek menurut sifat-sifat tertentu sesuai dengan konsepnya. 
3. Memberi contoh dan bukan contoh dari suatu konsep.

4. Menyajikan konsep dalam berbagai bentuk representasi matematis.

5. Mengembangkan syarat perlu atau syarat cukup dari suatu konsep.

6. Menggunakan dan memanfaatkan serta memilih prosedur atau operasi tertentu.

7. Mengaplikasikan konsep atau algoritma pada pemecahan masalah.

\section{METOE}

Jenis penelitian yang digunakan adalah penelitian dan pengembangan (research and development). Penelitian ini menggunakan modifikasi dari model 4D Thiagrajan, Semmel dan Semmel. 4D Thiagrajan, Semmel dan Semmel memiliki 4 tahapan yang terdiri dari define (pendefinisian), design (perancangan), develop (pengembangan), disseminate (penyebaran) (Trianto, $2011: 93$ ).

Empat tahapan pengembangan model 4D Thiagarajan, Semmel, dan Semmel dalam Trianto (2011 : 93-96) dan Widada (2012 : 4851) diuraikan sebagai berikut :

1. Tahap Pendefinisian Define)

Tujuan dari tahap ini adalah untuk menetapkan dan mendefinisikan kebutuhan-kebutuhan pembelajaran dengan menganalisis tujuan dan batasan materi. Tahap ini terdiri dari : 1) analisis awal akhir bertujuan untuk menentukan masalah mendasar yang dihadapi dalam pembelajaran; 2) analisis peserta didik bertujuan untuk menelaah peserta didik, dilakukan identifikasi terhadap karakteristik peserta didik yang sesuai dengan rancangan dan pengembangan pembelajaran; 3) analisis konsep bertujuan untuk mengidentifikasi konsep-konsep utama yang akan diajarkan, menyusunnya secara sistematis, dan memilah konsepkonsep yang relevan; 4) analisis tugas yakni menentukan dan merinci isi materi ajar dalam bentuk garis besar; dan 5) spesifikasi tujuan pembelajaran untuk melakukan penjabaran indikator pencapaian hasil belajar tujuan-tujuan pembelajaran khusus berdasarkan analisis konsep dan tugas yang telah dilakukan.

2. Tahap Perancangan (Design)

Tahap ini bertujuan untuk merancang perangkat pembelajaran, langkah dalam tahap perancangan yaitu : 1) penyusunan tes acuan patokan, merupakan langkah awal untuk menghubungkan tahap pendefinisian dan perancangan; 2) pemilihan media yang tepat untuk penyajian materi pelajaran; 3) pemilihan format untuk mengkaji format-format perangkat yang dikembangkan.

3. Tahap Pengembangan (Develop)

Tahap ini bertujuan untuk menghasilkan perangkat pembelajaran yang telah direvisi berdasarkan masukan dari validator dan data yang diperoleh dari uji coba lapangan. Perangkat yang dibuat harus melalui beberapa langkah berikut ini sebelum menjadi perangkat pembelajaran final : 1) validasi oleh para pakar untuk selanjutnya direvisi berdasarkan masukan para pakar;

2) simulasi, merupakan kegiatan mengoperasikan rencana pembelajaran; 3) uji coba terbatas dengan peserta didik yang sesungguhnya; dan 4) perancangan awal perangkat pembelajaran yang melibatkan aktivitas peserta didik dan pendidik, perancangan awal perangkat pembelajaran dapat berupa Rencana Pelaksanaan Pembelajaran (RPP), buku guru, buku peserta didik, LKPD, THB, dan seumber belajar lain yang sesuai dengan kebutuhan.

4. Tahap Penyebaran (Disseminate)

Tahap ini adalah tahap terakhir pada proses pengembangan model Thiagarajan, Semmel, dan Semmel. Perangkat pembelajaran yang telah memperoleh nilai positif dari tenaga ahli dan melalui tes pengembangan perangkat pembelajaran tersebut kemudian dikemas, disebarkan dan diterapkan untuk skala yang lebih luas.

Penulis hanya menerapkan 3 tahapan untuk melakukan penelitian yaitu define (pendefinisian), design (perancangan) dan develop (pengembangan) dan produk akhir dari 
pengembangan tidak akan disebar luaskan. Prosedur penelitian pengembangan telah dimodifikasi disajikan sebagai berikut.

Tabel 1. Prosedur Penelitian

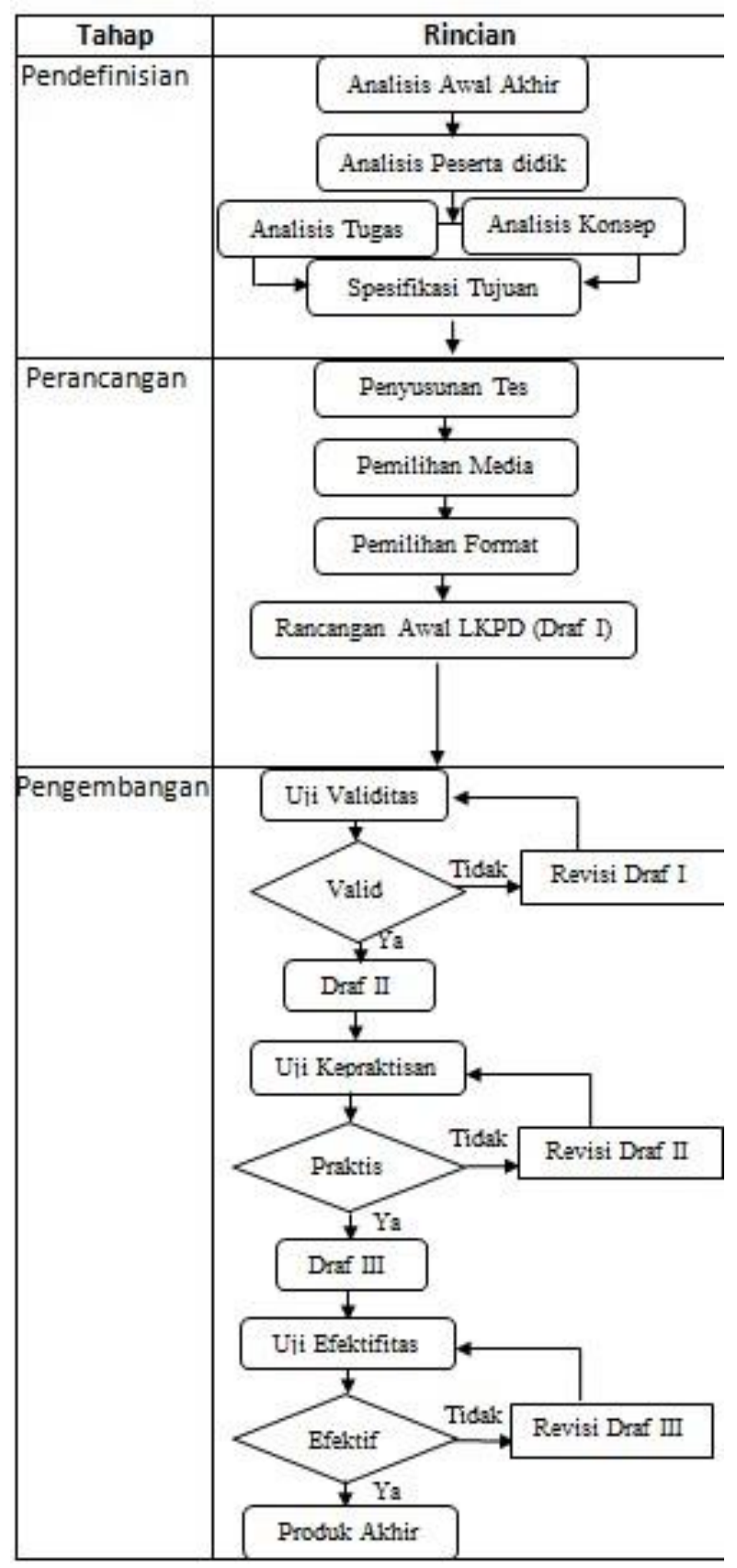

Sumber : Modifikasi Prosedur Penelitian Thiagarajan, Semmel, dan Semmel dalam (Trianto : 94)

Instrumen yang digunakan pada penelitian ini yaitu lembar efektifitas LKPD. Lembar efektifitas LKPD ini bertujuan untuk mengetahui LKPD yang dikembangkan sudah efektif atau belum. Lembar efektifitas LKPD meliputi lembar pengamatan lembar pengamatan aktivitas peserta didik, dan lembar respon peserta didik.

Teknik analisis data yang digunakan pada penelitian yaitu analisis Efektifitas LKPD. Analisis efektifitas dilakukan berdasarkan saran dan tanggapan dari penilai melalui lembar efektifitas serta nilai rata-rata hasil belajar peserta didik.

Untuk menganalisis efektifitas dilakukan berdasarkan saran dan pendapat dari penilaian lembar efektifitas serta nilai hasil belajar peserta didik. Hal yang perlu dilakukan untuk menganalisis LKPD dengan pendekatan saintifik adalah sebagai berikut :

a. Pemberian skor rata-rata aktivitas peserta didik dengan rumus :

$$
\overline{A P}_{1}=\frac{\sum_{i=1}^{n} \overline{A P}_{i}}{n} \quad \text { (Rumus }
$$

Diadaptasi Dari

Sudjana, 1975)

Keterangan :

$\overline{A P}_{1} \quad$ : rata-rata skor aktivitas pendidik oleh penilai ke-i

$\mathrm{AP}_{\mathrm{i}} \quad$ : skor aktivitas pendidik pertemuan ke-i

n : banyak pertemuan

Rata-rata skor aktivitas peserta didik keseluruhan dihitung dengan rumus :

$$
\overline{\mathrm{AP}}=\frac{\sum \overline{\mathrm{AP}_{\mathrm{i}}}}{\sum \text { penilai }}
$$

Untuk mendapatkan rata-rata aktivitas peserta didik harus disesuaikan dengan kriteria yang diberikan. Untuk menentukan kriteria tersebut dibutuhkan interval. Jika setiap butir pernyataan diberikan skor 1 sampai 5, sehingga untuk jumlah skor minimal dari 14 butir pernyataan adalah 14 dan jumlah skor maksimalnya adalah 70. Penentuan interval dapat dihitung dengan cara :

Total skor maksimal

$$
\begin{aligned}
\text { Interval } & =\frac{- \text { total skor minimal }}{\text { banyak kriteria }} \\
\text { Interval } & =\frac{70-14}{5} \\
\text { Interval } & =11,2
\end{aligned}
$$


Tabel 2. Kriteria Aktivitas Peserta DidikKriteria Aktivitas Peserta Didik

\begin{tabular}{|c|l|}
\hline Rentang Rata-rata aktivitas & \multicolumn{1}{|c|}{ Kriteria } \\
\hline $14 \leq \overline{A P}<25,2$ & Tidak Baik \\
\hline $25,2 \leq \overline{A P}<36,4$ & Kurang Baik \\
\hline $36,4 \leq \overline{A P}<47,6$ & Cukup Baik \\
\hline $47,6 \leq \overline{A P}<58,8$ & Baik \\
\hline $58,8 \leq \overline{A P} \leq 70$ & Sangat Baik \\
\hline
\end{tabular}

b. Menentukan efektifitas LKPD berdasarkan rata-rata skor respon peserta didik.

$$
\begin{aligned}
& \bar{R}_{1}=\frac{\sum_{i=1}^{n} \bar{R}_{i}}{n} \quad \text { (Rumus Diadaptasi } \\
& \text { Dari Sudjana, } \\
& \text { 1975) }
\end{aligned}
$$

Keterangan :

$\bar{R}_{1} \quad=$ skor rata-rata respon peserta didik

$\bar{R}_{i} \quad=$ total skor respon

peserta didik ke-i

$$
\mathrm{n} \quad=\text { banyak LKPD }
$$

Rata-rata skor respons peserta didik keseluruhan dihitung dengan rumus:

$$
\overline{\mathrm{R}}=\frac{\sum \overline{\mathrm{R}}_{\mathrm{i}}}{\sum \text { banyak peserta didik }}
$$

Untuk mendapatkan rata-rata respon peserta didik harus disesuaikan dengan kriteria yang diberikan. Jika setiap butir pernyataan diberikan skor 1 sampai 5, sehingga untuk jumlah skor minimal dari 15 butir pernyataan adalah 15 dan jumlah skor maksimalnya adalah 75. Sehingga didapat :

$$
\begin{aligned}
\text { Interval } & =\frac{\text { Total skor maksimal }}{\text { banyak kriteria }} \\
\text { Interval } & =\frac{75-15}{5} \\
\text { Interval } & =12
\end{aligned}
$$

Tabel 3. Kriteria Untuk Respon Peserta Didik

\begin{tabular}{|c|l|}
\hline Rentang Rata-rata aktivitas & \multicolumn{1}{|c|}{ Kriteria } \\
\hline $15 \leq \bar{R}<27$ & Tidak Baik \\
\hline $27 \leq \bar{R}<39$ & $\begin{array}{l}\text { Kurang } \\
\text { Baik }\end{array}$ \\
\hline $39 \leq \bar{R}<51$ & Cukup Baik \\
\hline $51 \leq \bar{R}<63$ & Baik \\
\hline $63 \leq \bar{R} \leq 75$ & Sangat Baik \\
\hline
\end{tabular}

c. Menentukan efektifitas LKPD berdasarkan persenatse peserta didik.

Rata-rata hasil belajar tiap pertemuan diambil dari $70 \%$ nilai THB dan $30 \%$ nilai pengerjaan LKPD.

Hasil tes dinilai dengan menggunakan 7 indikator pemahaman konsep. Untuk mencapai indikator tersebut minimal memenuhi kriteria baik dengan interval sebagai berikut. Jika skor maksimal adalah 2 maka interval $=\frac{2-0}{3}=0,67$.

Tabel 4. Kriteria Indikator Pemahaman Konsep

\begin{tabular}{|c|l|}
\hline Rentang Rata-rata aktivitas & \multicolumn{1}{|c|}{ Kriteria } \\
\hline $0-0,67$ & Kurang \\
\hline $0,67-1,34$ & Cukup \\
\hline $1,34-2$ & Baik \\
\hline
\end{tabular}

Menentukan rata-rata hasil belajar peserta didik dengan menggunakan rumus :

$$
\overline{\mathrm{X}}=\left(\frac{\sum \mathrm{T}}{\mathrm{N}_{1}} \times 70 \%\right)+\left(\frac{\sum \mathrm{L}}{\mathrm{N}_{2}} \times 30 \%\right)
$$

Keterangan :

$$
\begin{array}{ll}
\overline{\mathrm{X}} & : \text { Rata-rata hasil belajar } \\
\sum \mathrm{T} & \text { : Jumlah nilai pengerjaan THB } \\
\sum \mathrm{L} & \text { : Jumlah nilai pengerjaan LKPD } \\
\mathrm{N}_{1} & \text { : Jumlah THB } \\
\mathrm{N}_{2} & \text { : Jumlah LKPD }
\end{array}
$$

Suatu kelas dinyatakan memenuhi ketuntasan belajar klasikal jika minimal $75 \%$ peserta didik memperoleh nilai rata-rata hasil belajar minimal 75. Persentase ketuntasan belajar dengan rumus sebagai berikut:

$\mathrm{p}=\frac{\sum \text { peserta didik yang tuntas belajar }}{\sum \text { peserta didik }} \times 100 \%$

Keterangan:

$\mathrm{p}=$ Ketuntasan belajar

\section{HASIL DAN PEMBAHASAN Efektifitas LKPD}

Uji efektifitas dilaksanakan dengan melakukan uji coba di kelas VIII 1. Seluruh peserta didik yang berjumlah 32 orang mengerjakan LKPD secara kelompok. Peserta didik terbagi menjadi 9 kelompok, masingmasing kelompok terdiri dari tiga sampai 4 orang yang heterogen. Hasil penilaian uji efektifitas diambil dari penilaian pengamat terhadap aktivitas peserta didik, respon peserta didik, serta hasil belajar peserta didik yang 
terdiri dari penilaian pengerjaan LKPD dan THB.

Data hasil penilaian pengamat terhadap aktivitas peserta didik yang mengerjakan LKPD dengan Pendekatan Saintifik pada Materi Bangun Ruang Sisi Datar untuk Meningkatkan Pemahaman Konep Matematika Siswa Kelas VIII di SMPN 3 Kota Bengkulu diuraikan sebagai berikut.

Rata-rata skor aktivitas peserta didik pada pembelajaran menggunakan LKPD 1 adalah 65 dengan kategori baik. Rata-rata skor aktivitas peserta didik pada pembelajaran menggunakan LKPD 2 adalah 65 dengan kategori baik. Rata-rata skor aktivitas peserta didik pada pembelajaran menggunakan LKPD 3 adalah 69 dengan kategori sangat baik. Rata-rata skor aktivitas peserta didik pada pembelajaran menggunakan LKPD 4 adalah 67 dengan kategori sangat baik. Rata-rata skor aktivitas peserta didik secara keseluruhan adalah 66,5 dengan kategori sangat baik.

Penilaian terhadap aktivitas peserta didik menunjukkan bahwa saat mengerjakan LKPD 1 sampai 4, peserta didik telah melakukan kegiatan tahapan saintifik dengan baik.

Respon peserta didik terhadap LKPD terdiri dari 11 butir penilaian. Hasil respon peserta didik terhadap LKPD dengan Pendekatan Saintifik pada Materi Bangun Ruang Sisi Datar untuk Meningkatkan Pemahaman Konep Matematika Siswa Kelas VIII di SMPN 3 Kota Bengkulu diuraikan sebagai berikut.

Rata-rata skor respon peserta didik terhadap LKPD 1 adalah 63,71 dengan kategori sangat baik. Rata-rata skor respon peserta didik terhadap LKPD 2 adalah 64,12 dengan kategori sangat baik. Rata-rata skor respon peserta didik terhadap LKPD 3 adalah 64,12 dengan kategori sangat baik. Rata-rata skor respon peserta didik terhadap LKPD 4 adalah 63,56 dengan kategori sangat baik. Rata-rata skor respon peserta didik secara keseluruhan adalah 63,88 dengan kategori sangat baik.

Respon peserta didik menunjukkan bahwa kegiatan pembelajaran dengan menggunakan LKPD 1 sampai 4 dapat meningkatkan semangat mereka dalam belajar, membuat mereka lebih aktif dalam pembelajaran, mempermudah mereka untuk memahami materi, memberikan petunjuk yang dapat membantu mereka dalam proses menemukan konsep, memudahkan mereka mengetahui tujuan dan prosedur pembelajaran, membantu dalam memahami masalah.

Data hasil belajar peserta didik diambil dari $70 \%$ nilai THB dan $30 \%$ nilai pengerjaan LKPD. Peserta didik di kelas VIII 1 dinyatakan tuntas jika peserta didik memperoleh nilai minimal 75 (nilai KKM). Rata-rata keseluruhan hasil belajar peserta didik yaitu 79,97 dengan rata-rata untuk nilai LKPD yaitu 80,49 dan rata-rata untuk nilai THB yaitu 79,75. Nilai maksimum untuk nilai rata-rata LKPD yaitu

85 sedangkan nilai maksimum untuk nilai rata-rata THB yaitu 80,34 . Nilai minimum untuk nilai rata-rata LKPD yaitu 74,3 sedangkan nilai minimum untuk nilai rata-rata THB yaitu 79.18. Data hasil belajar peserta didik menunjukkan bahwa sebanyak 26 peserta didik tuntas belajar dengan ketuntasan klasikal yaiktu $81,25 \%$. Hal ini berarti peserta didik telah memenuhi kategori ketuntasan klasikal dengan persentase minimal $80 \%$, sehingga dapat dinyatakan bahwa LKPD dengan Pendekatan Saintifik pada Materi Bangun Ruang Sisi Datar untuk Meningkatkan Pemahaman Konep Matematika Siswa Kelas VIII di SMPN 3 Kota Bengkulu dikategorikan efektif berdasarkan nilai hasil belajar peserta didik.

Aktivitas yang dilakukan oleh peserta didik menyesuaikan dengan kegiatan pada pendekatan saintifik. Kegiatan yang pertama yaitu mengamati. Pada kegiatan ini peserta didik diberikan suatu informasi yang akan diamati. Informasi ini dibuat dengan ketentuan pada kegiatan yang berikutnya yaitu menanya. Jadi pada kegiatan mengamati, peserta didik dipancing agar bisa membuat pertanyaan dari apa yang telah diamati. Hal ini bertujuan agar peserta didik berpikir menalar tentang apa yang mereka amati.

Aktivitas yang kedua yaitu kegiatan menanya. Pada tahapan ini peserta didik 
membuat pertanyaan dari kegiatan mengamati. Pertanyaan yang diharapkan adalah pertanyaan yang sesuai dengan materi yang akan dipelajari hari itu. Hal ini bertujuan agar peserta didik belajar untuk menalar membuat pertanyaan yang diperlukan untuk kegiatan mengamati. Agar pertanyaan yang dibuat tidak melencang dari yang diharapkan sehingga peran guru disini adalah membimbing peserta didik untuk membuat pertanyaan. Selain itu juga sudah dibuatkan syarat pertanyaan yang harus dibuat pada LKPD yang dikembangkan.

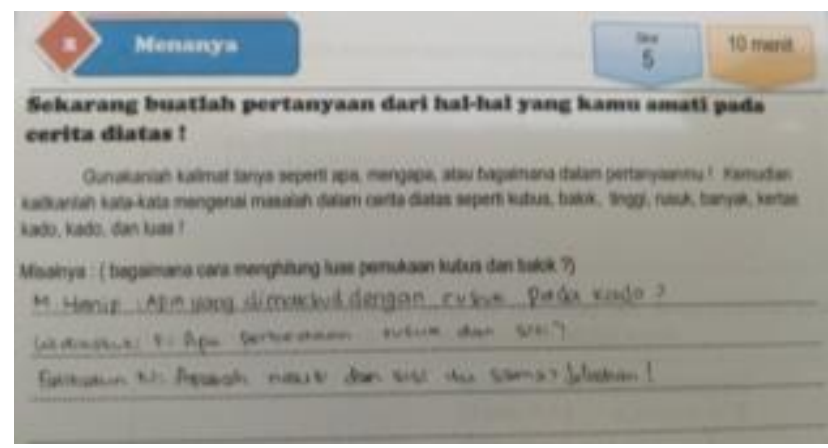

Gambar 1. Contoh Pekerjaan Peserta Didik dalam Membuat Pertanyaan

Gambar 1 menunjukkan contoh peserta didik membuat pertanyaan mengenai kegiatan mengamati materi yang dibahas, dari gambar tersebut terlihat peserta didik sudah mampu membuat pertanyaan-pertanyaan.

Aktivitas yang ketiga yaitu kegiatan mengumpulkan informasi. Pada tahapan ini peserta didik mengumpulkan informasi dari berbagai sumber yang diperlukan untuk dapat menjawab pertanyaan yang telah dibuat pada tahapan menanya dan membantu peserta didik dalam menemukan konsep pada materi yang dipelajari dengan cara mengukur, menghitung, dan mengisi tabel. Hal ini bertujuan untuk melatih peserta didik untuk mencari informasi yang dibutuhkan untuk menemukan konsep materi yang akan dipelajari.

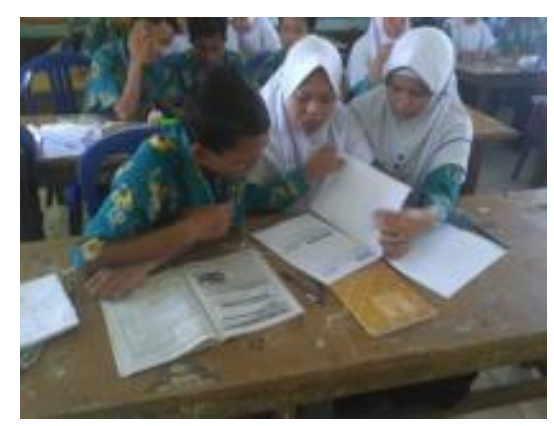

Gambar 2 Kegiatan peserta didik pada kegiatan mengumpulkan informasi

Dari gambar 2 terlihat peserta didik melakukan mengumpulkan informasi dari berbagai sumber. Berikut contoh pekerjaan peserta didik dalam mengumpulkan informasi.

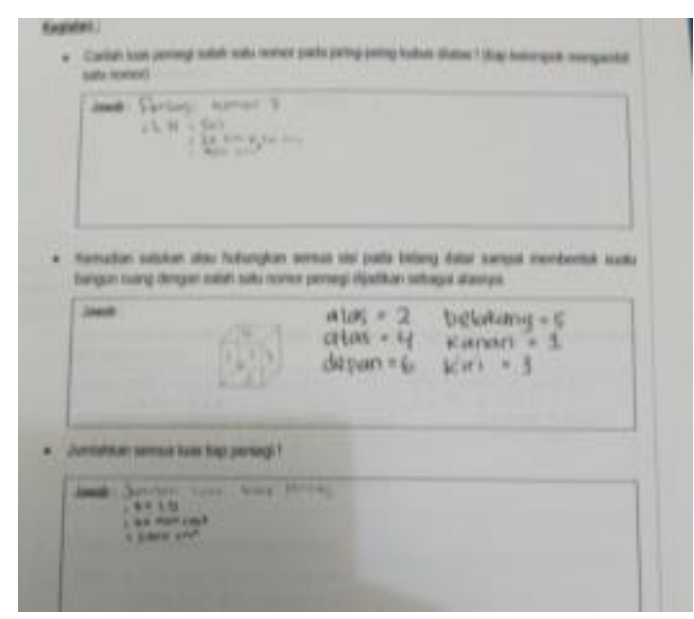

Gambar 3 Contoh pekerjaan peserta didik dalam mengumpulkan informasi

Gambar 3 menunjukkan hasil pekerjaan peserta didik yang didapatkan dari hasil pengukuran yang dapat melatih peserta didik dalam meningkatkan pemahaman konsep matematikanya. Indikator pemahaman konsep matematika yang terdapat pada kegiatan ini seperti mengulang suatu konsep, mengaplikasikan konsep, dan menggunakan prosedur tertentu pada suatu konsep.

Aktivitas selanjutnya yaitu kegiatan mengolah informasi. Pada tahapan ini peserta didik mengolah informasi yang telah didapatkan sebelumnya. Pada kegiatan ini peserta didik mengolah informasi yang didapat dan menerapkan konsep yang diperoleh untuk menyelesaikan masalah yang diberikan. Hal ini 
juga bertujuan untuk melatih atau mengembangkan pemahaman konsep matematika yang telah diperoleh dari informasi sebelumnya.

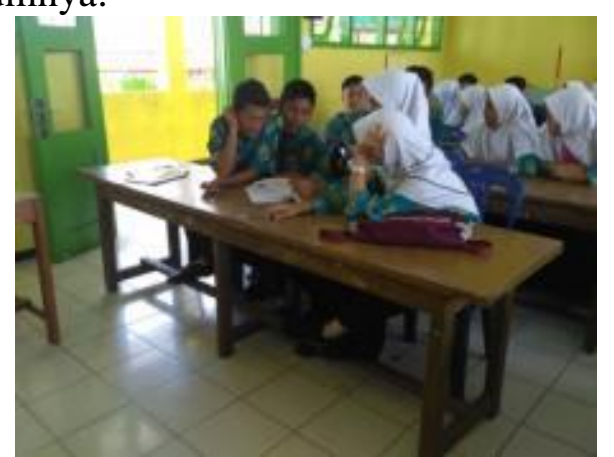

Gambar 4. Kegiatan peserta didik mengolah informasi

Dari gambar diatas terlihat kegiatan peserta didik berdiskusi untuk melakukan pengolahan informasi dengan menggunakan data atau informasi yang ada pada kotak mengolah informasi. Berikut contoh pekerjaan peserta didik pada kegiatan mengolah informasi.

Peserta didik sudah mampu mengolah informasi dengan cara mengisi pertanyaan dan menjawab pertanyaan dengan menggunakan informasi yang telah mereka dapatkan pada tahap pengumpulan informasi.

Selanjutnya adalah kegiatan menyimpulkan. Menyimpulkan disini adalah menyimpulkan semua kegiatan sebelumnya yaitu kegiatan mengamati, menanya, mengumpulkan informasi, dan mengolah informasi dan mengisinya pada kotak yang ada pada LKPD. Berikut contoh pekerjaan peserta didik dalam menarik kesimpulan

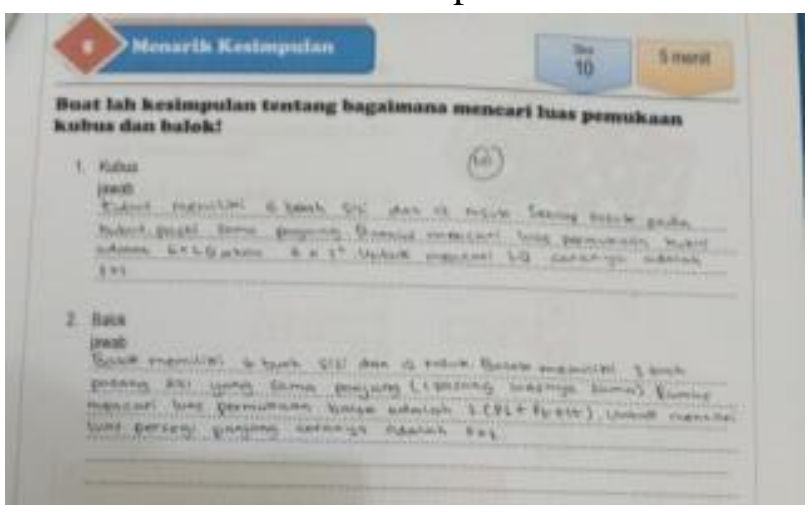

Gambar 5. Contoh pekerjaan peserta didik pada kegiatan menyimpulkan
Gambar diatas menunjukkan pekerjaan peserta didik pada kegiatan menarik kesimpulan, dari gambar 5 dapat dilihat peserta didik sudah mampu menarik kesimpulan mengenai materi yang diajarkan dari kegiatan sebelumnya.

Aktivitas selanjutnya yaitu kegiatan mengomunikasikan. Pada kegiatan ini peserta didik menyampaikan hasil pengerjaan kelompoknya di depan kelas. Berikut gambar kegiatan peserta didik dalam mengomunikasikan.

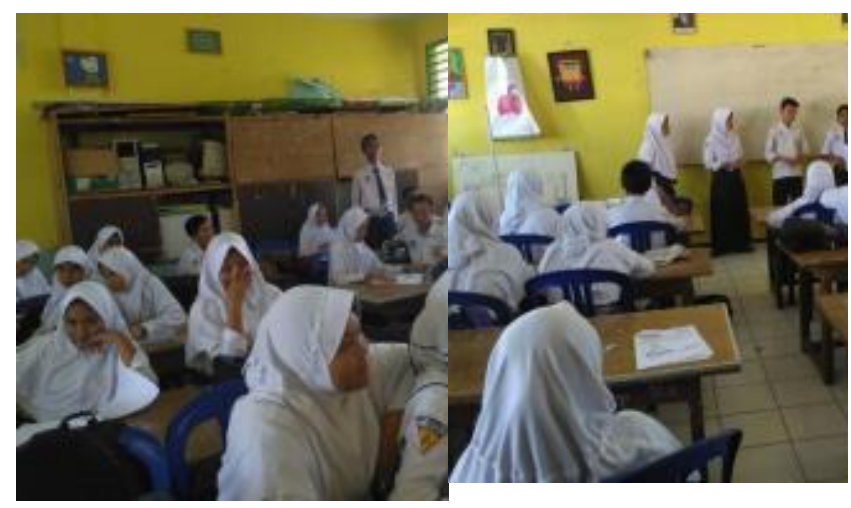

Gambar 6 Contoh pekerjaan peserta didik pada kegiatan mengomunikasikan

Dari gambar diatas terlihat bahwa peserta didik sudah mampu mengomunikasikan hasil yang telah mereka dapat dan diskusikan bersama teman kelompok. Terlihat bahwa ada peserta didik dari kelompok lain yang bertanya. Hal ini menunjukkan bahwa kegiatan mengomunikasikan berjalan dengan baik dan dengan bimbingan guru. Setelah itu hasil dari kegiatan tersebut dibuat pada kotak kegiatan mengomunikasikan dengan pertanyaan pertanyaan dari kelompok lain kemudian didiskusikan pada kelompok penyaji selanjutnya disampaikan jawaban didepan kelas. Apabila masih sulit di terima maka guru akan membimbing untuk menjawab pertanyaan yang diberikan.

Secara keseluruhan aktivitas peserta didik sudah baik. Hal ini ditunjukkan dengan hasil pengamatan yang dilakukan oleh pengamat yaitu guru pamong. Dari hasil pengamatan, peserta didik sudah dapat bekerja sama dengan teman sekelompok dan mengerjakan LKPD dengan baik. Hasil pengamatan yang dilakukan 
oleh pengamat yaitu dengan mengisi lembar aktivitas peserta didik diperoleh skor rata-rata 66,5 dengan kriteria sangat baik.

\section{Respons Peserta Didik}

Respons peserta didik diperoleh dari lembar respons peserta didik yang diisi oleh peserta didik. Lembar respons peserta didik ini dilakukan untuk melihat bagaimana pendapat peserta didik terhadap LKPD yang sedang dikembangkan. Aspek pernyataan pada lembar respon peserta didik ini berkaitan dengan pembelajaran saintifik yang bertujuan untuk meningkatkan pemahaman konsep matematika peserta didik kelas VIII. Respon peserta didik memenuhi kriteria sangat baik dengan skor ratarata 63,88. Dengan demikian respons peserta didik terhadap LKPD 1 samapai LKPD 4 dapat dinyatakan sangat efektif.

Respon peserta didik diperoleh dari angket yang berisi mengenai pendapat peserta didik terhadap LKPD yang telah mereka kerjakan. Perolehan skor rata-rata dengan kriteria sangat baik telah didapat dari hasil yakni lebih dari $70 \%$ peserta didik memberikan respons baik dan sangat baik.

\section{Hasil Belajar Peserta Didik}

Tes Hasil Belajar (THB) diberikan per dua LKPD. Jadi, setiap dua pertemuan dilakukan tes. THB terdiri dari lima soal essay yang disusun berdasarkan indikator yang ingin dicapai pada materi bangun bangun ruang sisi datar. Hasil belajar peserta didik diperoleh dari $70 \%$ nilai $\mathrm{THB}$ dan $30 \%$ nilai pengerjaan LKPD. Empat LKPD diberikan kepada peserta didik yang berjumlah 32 yang dibagi menjadi beberapa kelompok. LKPD tersebut dibagi menjadi dua LKPD membahas luas permukaan bangun ruang sisi datar dan dua LKPD membahas volume bangun ruang sisi datar. Tes Hasil belajar dilakukan sebanya dua kali, yang pertam materi luas permukaan bangun ruang sisi datar dan yang kedua tentang volume bangun ruang sisi datar. Penilaian Tes dilakukan berdasarkan indikator pemahaman konsep untuk mencapai indikator pembelajaran yang telah ditentukan. Berikut adalah dokumentasi peserta didik mengerjakan soal THB.

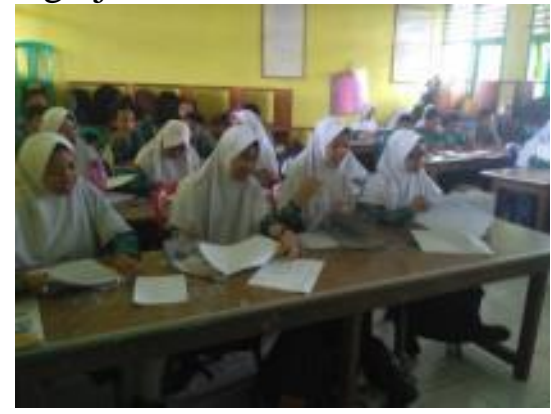

Gambar 7. Dokumentasi peserta didik saat Tes Hasil Belajar (THB)

Tes Hasil Belajar yang pertama terdiri dari 5 soal yang sudah divalidasi. LKPD yang diberikan pada saat proses pembelajaran mempunyai pengaruh terhadap penerapan konsep pada pokok bahasan bangun ruang sisi datar. Pernyataan ini dapat dilihat dari jawabanjawaban peserta didik pada lembar THB. Berikut ini adalah salah satu contoh dari jawaban peserta didik pada soal no satu di lembar THB.

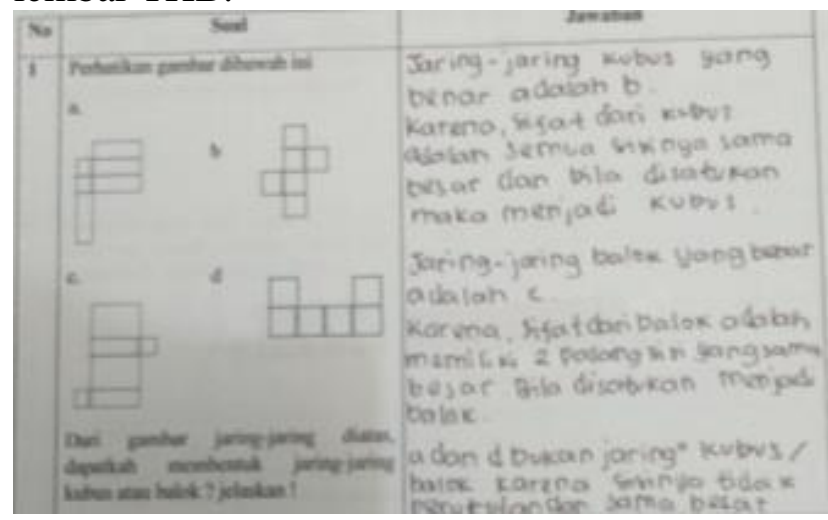

Gambar 8. Jawaban THB peserta didik nomor satu

Soal nomor satu merupakan soal yang dibahas konsepnya pada proses pembelajaran dengan menggunakan LKPD 1. Peserta didik akan memenuhi indikator pemahaman konsep yaitu menyatakan ulang suatu konsep, mengklasifikasikan objek menurut sifat tertentu, dan memberikan contoh dan bukan contoh dari suatu konsep. Hal ini cukup memperlihatkan bahwa LKPD mempunyai pengaruh terhadap hasil jawaban peserta didik sehingga jawaban peserta didik benar. 
Akan tetapi masih ada peserta didik yang menjawab soal nomor satu dengan jawaban yang kurang lengkap. Peserta didik hanya menyebutkan tan menjelaskan dengan lengkap jawaban pada nomor 1. Berikut jawaban peserta didik yang salah.

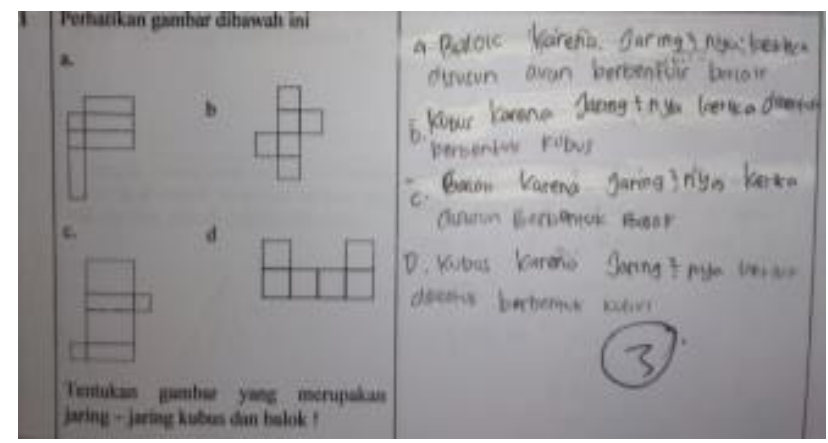

Gambar 9. Jawaban THB peserta didik nomor satu yang salah.

Dari jawaban peserta didik diatas dapat dilihat masih ada peserta didik yang menyebutkan mana yang merupakan jaringjaring balok atau kubus. Secara keseluruhan hampir semua peserta didik dapat menjawab soal nomor satu hanya saja masih terdapat yang menjawab kurang lengkap.

Soal nomor dua dan tiga merupakan pembahasan dari materi di LKPD 1 tentang luas permukaan kubus dan balok. Hampir 100\% peserta didik dapat menjawab dengan benar dan lengkap. Berikut contoh hasil pengerjaan dari peserta didik.

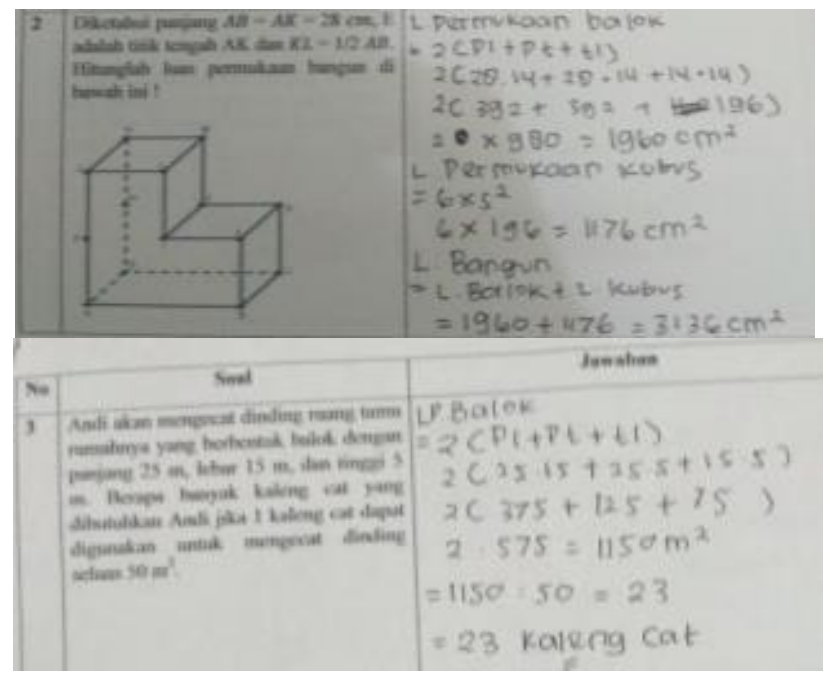

Gambar 10. Jawaban THB peserta didik nomor dua dan tiga yang benar
Dari gambar diatas dapat dilihat peserta didik sudah dapat menerapkan rumus yang didapatkan pada saat pengerjaan LKPD, dimana peserta didik dapat menerapkan dan menghitung luas permukaan bangun ruang sisi datar gabungan dari bangun ruang kubus dan balok, hanya saja masih ada beberapa peserta didik yang masih keliru dalam mengambil ukuran yang ditentukan mereka sendiri untuk menghitungnya sehingga jawaban tersebut tidak lengkap.

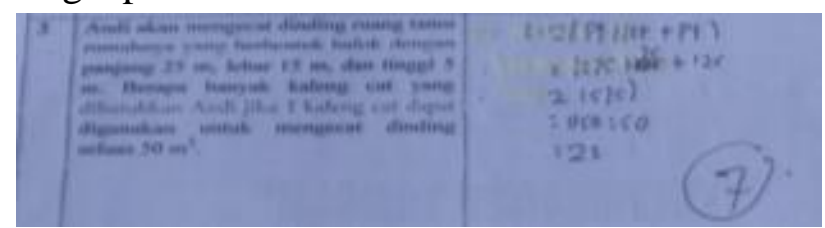

Gambar 11. Jawaban THB peserta didik nomor dua dan tiga yang tidak lengkap

Dari gambar diatas ada peserta didik yang masih bingung menentukan ukuran dari bangun ruang datar tersebut untuk mencari luas permukaan gabungan dari bangun ruang tersebut sehingga jawaban peserta didik tersebut tidak lengkap. Indikator yang terdapat pada soal nomor dua yaitu menyatakan ulang suatu konsep dan mengaplikasikan suatu konsep. Setelah itu untuk jawaban nomor 3 masih ada peserta didik yang menjawab tidak lengkap seperti tidak menuliskan satuan dari hasil akhirnya dan prosedur yang dipilih kurang jelas. Indikator pemahaman konsepnya yaitu menyatakan ulang suatu konsep, menggunakan syarat perlu dan syarat cukup, menggunakan dan memilih prosedur operasi tertentu, dan mengaplikasikan konsep.

Soal nomor 4 dan 5 merupakan materi dari LKPD 2 yaitu luas permukaan limas dan prisma. Berikut salah satu contoh jawaban yang benar untuk soal no 4 dan 5 .

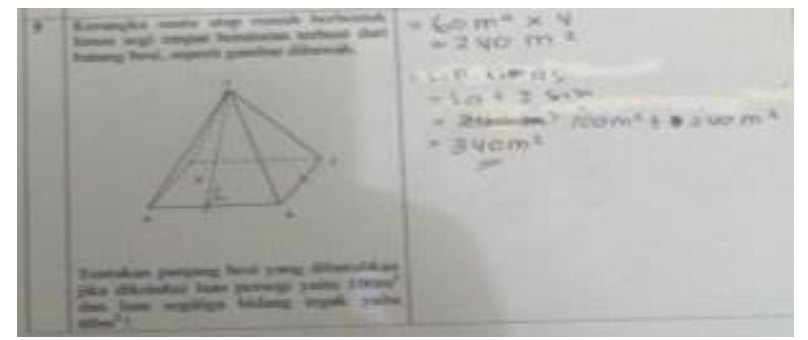

Gambar 12. Jawaban THB peserta didik nomor 5 yang benar 
Peserta didik masih banyak menjawab salah pada soal nomor 5 pada soal pembahasan luas permukaan dari limas. Peserta didik masih salah dalam menyatakan ulang konsep dari limas sehingga membuat jawaban menjadi tidak lengkap atau salah. Kemudian banyak peserta didik yang tidak menjawab pertanyaan pada soal nomor 5. Berikut salah satu contoh jawaban peserta didik yang salah atau tidak lengkap.

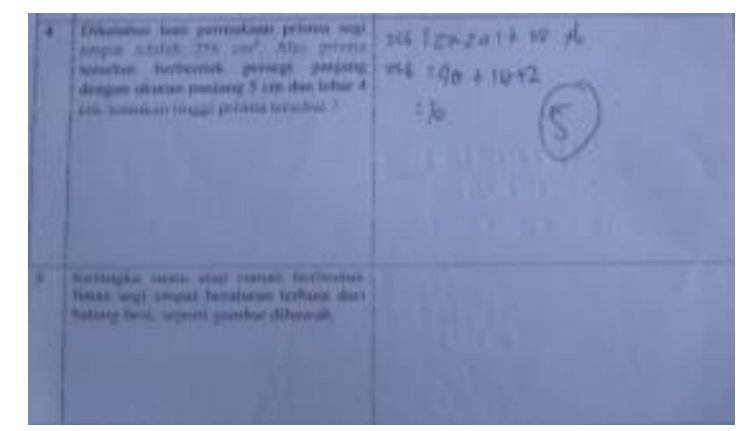

Gambar 13. Jawaban THB peserta didik nomor 4 dan 5 yang tidak lengkap

Tes hasil belajar yang kedua terdiri dari 5 butir soal esay yang merupakan soal tentang volume bangun ruang sisi datar yang telah dipelajari pada LKPD 3 dan LKPD 4. Soal nomor 1,2 dan 4 merupakan soal tentang volume kubus dan balok yang telah dipelajari di LKPD 3 sedangkan pada soal nomor 3 dan 5 tentang volume limas dan prisma yang telah di pelajari pada LKPD 4.

Soal nomor satu merupakan soal tentang volume kubus dan balok. Peserta didik diminta untuk memilih dan menjelaskan definisi dari kubus dan balok tersebut apa menurut contoh yang telah mereka pilih dari gambar. Indikator pemahaman konsepnya adalah menyatakan ulang suatu konsep, mengklasifikasikan objek menurut sifat tertentu dan memberikan contoh dan bukan contoh dai suatu konsep. Berikut salah satu contoh jawaban peserta didik.

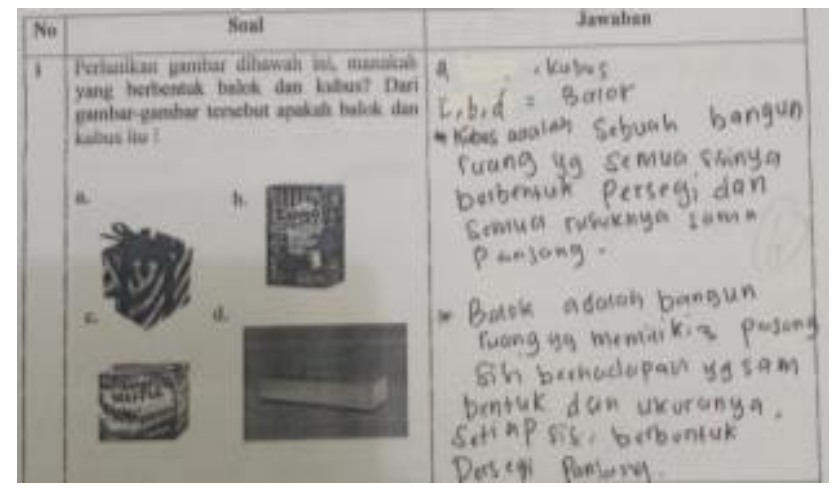

Gambar 14. Jawaban THB peserta didik nomor 1 yang benar

Gambar diatas menunjukkan bahwa peserta didik telah mampu menjawab soal dengan benar dan lengkap. Akan tetapi masih ada beberapa peserta didik yang menjawab salah ataupun kurang lengkap, karena peserta didik hanya menyebutkan dan tidak menjelaskan definisi kubus dan balok tersebut. Berikut contoh jawaban peserta didik yang kurang lengkap.

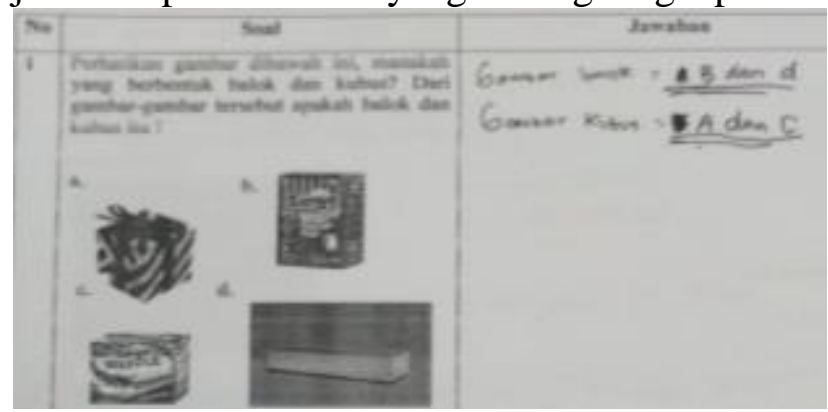

Gambar 15. Jawaban THB peserta didik nomor 1 yang tidak lengkap

Nomor dua THB disini masih membahas materi tentang volume kubus dan balok. Indikator yang memenuhi adalah menyatakan ulang suatu konsep, dan menggunakan syarat perlu dan syarat cukup. Berikut salah satu contoh jawaban peserta didik.

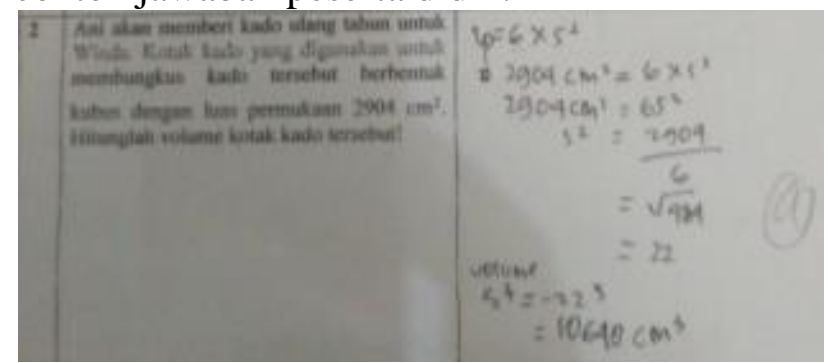

Gambar 16. Jawaban THB peserta didik nomor 2 yang benar 
Lebih dari $90 \%$ peserta didik dapat menjawab soal dengan benar. Adapun kekurangan jawaban didalam mengisi pertanyaan tersebut peserta didik kurang dalam memberikan satuan dikarenakan mungkin mereka lupa untuk menuliskannya.

Pada soal nomor 3 dan 5 membahas soal mengenai volume limas dan prisma yang telah dikerjakan pada LKPD 4. Indikator pemahaman konsep yang ada pada soal nomor 3 yakni menyatakan ulang suatu konsep, menggunakan syarat perlu dan syarat cukup, menggunakan, memanfaatkan, dan memilih prosedur tertentu, serta mengaplikasikan suatu konsep dalam penyelesaian masalah. Berikut salah satu contoh jawaban peserta didik.

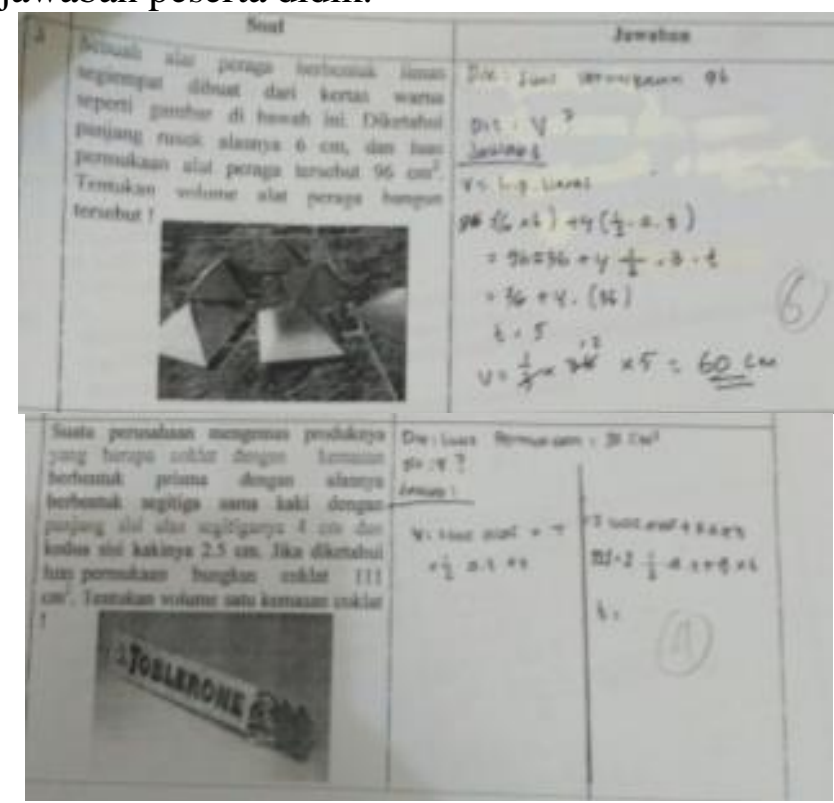

Gambar 17. Jawaban THB peserta didik nomor

3 dan 5

Gambar diatas menunjukkan peserta didik sudah dapat menjawab soal dengan benar dan lengkap. Pada soal nomor 3 hampir semua peserta didik menjawab salah ataupun kurang tepat karena mereka masih bingung syarat perlu dan syarat cukup dari suatu konsep sehingga jawaban mereka salah. Begitu pula untuk jawaban soal nomor 5 karena kedua soal hampir sama harus mencari tinggi dari bangun ruang tersebut barulah bisa mencari volume dari limas dan prisma yang ditanyakan.
Selanjutnya pada soal nomor 4 merupakan soal tentang volume balok yang telah dipelajari pada LKPD 3. Indikator pemahaman konsep pada soal adalah menyatakan ulang suatu konsep, menyatakan konsep dalam berbagai bentuk representasi matematis, menggunakan, memanfaatkan, dan memilih prosedur tertentu pada suatu konsep, serta mengaplikasikan suatu konsep untuk penyelesaian masalah. Berikut salah satu contoh jawaban peserta didik.

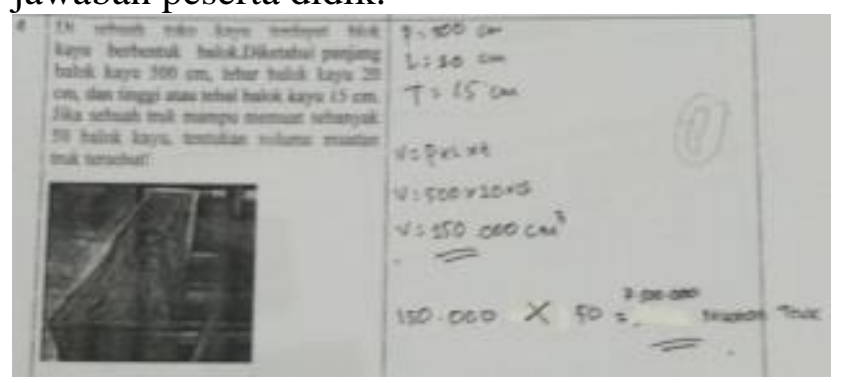

Gambar 18. Jawaban THB peserta didik nomor 4 yang benar

Gambar diatas menunjukkan bahwa peserta didik sudah mampu menjawab dengan lengkap dan benar sehingga indikator pemahaman konsepnya terpenuhi. Hampir $100 \%$ peserta didik menjawab soal dengan benar akan tetapi masih ada beberapa yang kurang atau lupa memberikan satuan dari jawaban tersebut.

Penilaian tes berdasarkan indikator pemahaman konsep yang terdiri dari 7 indikator pemahaman konsep pada THB 1 dan THB 2 . Hasil belajar peserta didik dinyatakan lulus secara klasikal karena hasil belajar mencapai $81,25 \%$. Hal ini menunjukkan bahwa pemahaman konsep matematika peserta didik telah meningkat dari kegiatan pembelajaran menggunakan LKPD dalam menyelesaikan soal tes yang diberikan. Ditunjukkan oleh hasil pengerjaan tes hasil belajar dengan penilaian indikator pemahaman konsep. Pada THB 1 semua indikator pemahaman konsep mendapatkan skor rata-rata dengan kriteria baik.

Hal tersebut menunjukkan bahwa LKPD yang telah dikerjakan dapat meningkatkan pemahaman konsep peserta didik. Sedangkan pada THB 2 terdapat satu indikator yang memiliki skor rata-rata dengan kriteria cukup 
pada indikator ke 2 yaitu mengklasifikasikan objek menurut sifat tertentu. Akan tetapi 6 indikator yang lain mendapatkan kriteria baik maka pada hasil THB 2 juga menunjukkan bahwa LKPD yang telah dikerjakan dapat meningkatkan pemahaman konsep matematika siswa kelas VIII.

\section{PENUTUP}

\section{Simpulan}

Kesimpulan dari hasil penelitian terhadap efektifitas pengembangan LKPD dengan Pendekatan Saintifik pada Materi Bangun Ruang Sisi Datar untuk Meningkatkan Pemahaman Konep Matematika Siswa Kelas VIII di SMPN 3 Kota Bengkulu yaitu LKPD menggunakan pendakatan saintifik untuk meningkatkan pemahaman konsep matematika siswa pada materi bangun ruang sisi datar kelas VIII SMPN 3 Kota Bengkulu berkategori efektif berdasarkan pengamatan aktivitas peserta didik dengan skor rata-rata 66,5, sangat baik, berdasarkan respon peserta didik dengan skor rata-rata 63,88; dan tuntas secara klasikal berdasarkan hasil belajar peserta didik dengan persentase mencapai $81,25 \%$. Deskripsi LKPD yang telah melalui tahap uji efektifitas sebagai berikut.

a. LKPD telah disusun berdasarkan syaratsyarat penyusunan LKPD sehingga LKPD dapat membantu peserta didik mencapai tujuan pembelajaran.

b. LKPD sudah membuat peserta didik melaksanakan proses pembelajaran sesuai dengan kaidah pendekatan saintifik sehingga peserta didik memperoleh hasil belajar yang tinggi.

c. LKPD sudah dapat meningkatkan kemampuan pemahaman konsep matematika pada materi bangun ruang sisi datar

d. Hasil belajar peserta didik menunjukkan bahwa sebanyak 26 peserta didik tuntas belajar dengan ketuntasan klasikal yaitu $81,25 \%$. Hal ini berarti peserta didik telah memenuhi kategori ketuntasan klasikal dengan persentase lebih dari presentase ketuntasan klasikal minimal yaitu $80 \%$.

\section{Saran}

Saran yang diberikan penulis berdasarkan penelitian yang telah dilakukan disajikan sebagai berikut.

1. LKPD sebaiknya menggunakan ilustrasi dari berbagai aktivitas yang sering ditemui pada kehidupan sehari-hari untuk mempermudah peserta didik dalam memahami dan menemukan konsep.

2. Untuk melakukan tes hasil belajar sebaiknya kondisikan jumlah soal dan waktu pengerjaan soal.

3. Pada saat mengerjakan LKPD dengan bimbingan dari guru sebaiknya kondisikan kelas agar tidak ribut karena banyak peserta didik yang bertanya. Masalah ini dapat diatasi dengan menampung beberapa pertanyaan dan yang sama bisa disampaikan secara keseluruhan didepan kelas.

4. Kegiatan saintifik yang dilakukan juga harus diperhatikan sebaiknya berikan beberapa gambaran yang cukup jelas yang mengarah kepada pertanyaan tersebut agar tidak membuat peserta didik sulit untuk membuat pertanyaan.

\section{DAFTAR PUSTAKA}

Apriyanto (2015) : "Penerapan Pendekatan Saintifik Berbantuan Penilaian Proyek Untuk Meningkatkan Hasil Belajar Matematika Siswa Kelas VIII.2 SMP Negeri 4 Kota Bengkulu”. Bengkulu : Program Sarjana Universitas Bengkulu

Aqib, Z., dan Amrullah, A. (2017). Pedoman Pendidikan Budaya Dan Karakter Bangsa. Yogyakarta: Penerbit Gava Media.

Dahar, R. W. (1989). Teori-teori Belajar. Bandung: Erlangga.

Depdiknas. (2008). Panduan Pengembangan

Bahan Ajar. Jakarta: Departemen

Pendidikan Nasional.

Hosnan, M. (2014). Pendekatan Saintifik Dan Kontekstual Dalam Pembelajaran Abad 21. Bogor: Ghalia Indonesia. 
Musfiqon, \& Nurdiansyah. (2015). pendektan pembelajaran saintifik. Sidoarjo: Nizamia Learning centre.

Nurdin, S., dan Adriantoni. (2016). Kurikulum dan Pembelajaran. Jakarta: PT Raja Grafindo Persada.

Prastowo, A. (2011). Panduan Kreatif Membuat Bahan Ajar Inovatif. Jogjakarta: DIVA press.

Sardiman. (2010). interaksi dan motivasi belajar. jakarta: Rajawali Persada.

Trianto. (2011). Model Pembelajaran Terpadu. Jakarta: BUmi Aksara.

Widada, W. (2007). Pengembangan Teori Perkembangan Skema (triad level) tentang kalkulus pada mahasiswa. jurnal inspirasi VI. 